31. Vassalou M. (2000) Exchange Rate and Foreign Inflation Risk Premiums in Global Equity Return. Journal of International Money and Finance, vol. 19, no. 7, pp. 433-470.

32. Wu H. (2008) International asset pricing models: A forecasting evolutions. International Research Journal of Finance and Economics, vol. 15, no. 3, pp. 175-184.

\title{
INTERRELATION BETWEEN PAYOUT AND FINANCING DECISIONS: EVIDENCE FROM EMERGING MARKETS
}

\author{
Artem Anilov, \\ Post-graduate, National Research University Higher School of Economics \\ Russia,Moscow, Shabolovka str., 26.E-mail: Tema_anilov@mail.ru \\ Nikita Pirogov, \\ Senior lecturer National Research University Higher School of Economics \\ Russia,Moscow, Shabolovka str.,26.E-mail:npirogov@hse.ru
}

\begin{abstract}
Financing and payout decisions generally affect company's economic performance: they have impact (both directly and indirectly) on the free cash flow and, thus, on company's and shareholders' value. Search for optimal capital structure and optimal payout policy strategy that are likely to maximize shareholders' utility resulted in the papers, dedicated to determinants of capital structure and payout policy. In such papers, one of the policies is usually treated as a determinant for another one. This bound does not let researchers to make some conclusions about existence or absence of interrelation between payout and financing choices. To capture this interrelation, simultaneous regression analysis should be performed. Researchers, though, cannot come up with unified conclusion about the existence and direction of such interrelation.

The absence of certain results as well as low level of research done on emerging markets make this topic rather relevant.

The results of recent research on the interrelation between payout and financing decisions are discussed in this paper. We also develop an econometric model that allows us to check the existence of interrelation in emerging markets and to compare the results to those obtained from developed markets.

The article contributes to the existed literature in the following directions: first, two debt variables are taken into account (total and long-term debt) as well as two payout policy variables (total payout and dividend payout). Second, macroeconomic variables are controlled. Third, the results obtained from the companies from emerging countries are compared to those obtained from developed markets.
\end{abstract}

Keywords: capital structure; payout policy; emerging markets; corporate finance; simultaneous regression JEL: G32, G35

\section{Introduction}

Capital structure and dividend policy are among of the most researched topics in corporate finance. In 1958 and 1961, Modigliani and Miller published two papers, dedicated to capital structure and dividend policy respectively. The main conclusions of these papers are those about irrelevance of financing and payout policies in terms of value creation under some assumptions (absence of corporate taxes, absence of transaction costs, and absence of information asymmetry) [Modigliani, Miller, 1958; Modigliani, Miller, 1961].

In the real world, these assumptions never hold and MM's theorems do not work. This means that financing and payout decisions actually may affect the company's value. By somehow adjusting capital structure and dividend policy, the management is able to reach the aim of value maximization. 
On the one hand, for example, when the corporate taxes actually exist, there will be a positive effect of a tax shield, which will reduce interest payments by the amount of tax rate. The company's value will increase by the amount of present value of this tax shield effect (PVTS) minus costs of financial distress (COFD; when the company increases its debt, PVTS also increases, as well as the financial distress probability). On the other hand, the company may use payout policy as the positive signal to markets [Liu, Shan, 2007], which will result in stock price go higher and increase in company's value.

Let us discuss a way of interrelation between financing and payout decisions ${ }^{1}$.

The main goal of any commercial company is making profit. Net income may be distributed in two ways: it may be invested in some projects or it can be paid out to the company's shareholders. Net income in this case can be considered as the internal source of financing. Cash holdings also may be considered as the internal sources. Obviously, there can be a situation, when net income and other internal sources are not enough for meeting both the needs of strategic investments and shareholders' interests. In such cases, the managers can make a decision to draw some external funds, i.e. either debt financing or equity financing (Picture 1.). The choice between these two alternatives will depend on the cost of debt and cost of equity.

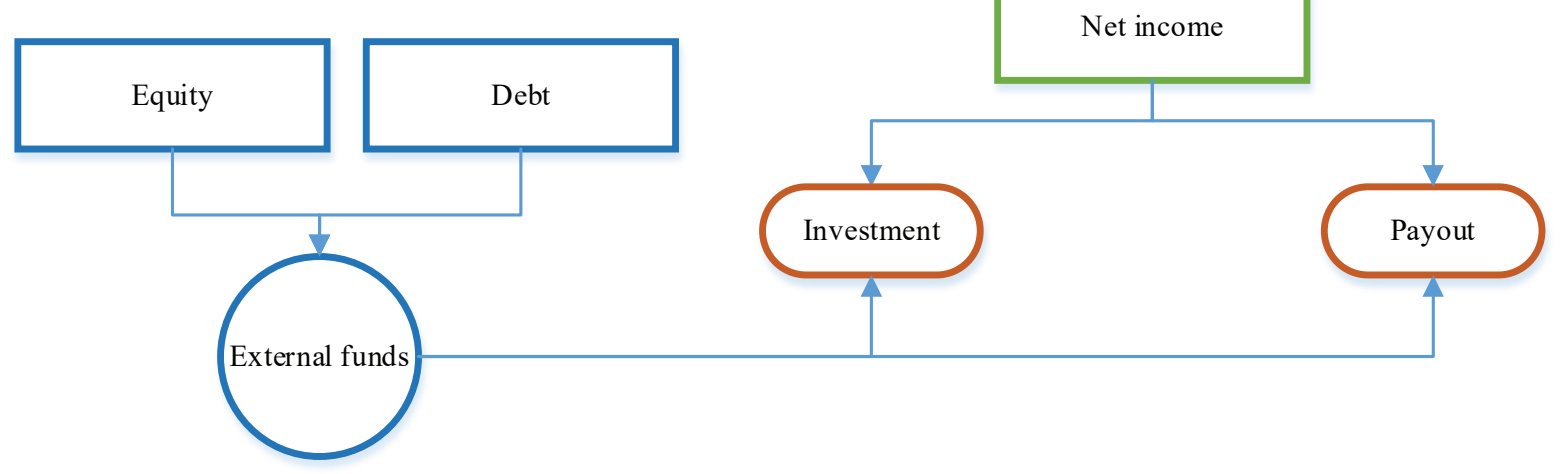

Picture 1. Interrelation between financing and payout decisions

The interrelations of variables, depicted on Picture 1, determine the relations between financing and payout decisions.

In the paper by Lambrecht and Myers authors came up with a simple budget constraint equation that puts a picture above in a mathematical way [Lambrecht, Myers, 2012]:

$\Delta$ Debt $+\Delta E q u i t y+$ Net Income $=$ CapEx + Payout.

Let us try to develop this idea and discuss some possible situations that show these interrelations in practice.

Table 1

The possible ways of interrelation between financing and payout decisions.

\begin{tabular}{|c|c|c|c|c|}
\hline Variable & Capital Expenditures & Net income & Debt & Payout to shareholders \\
\hline \multirow{2}{*}{$\begin{array}{c}\text { Направление } \\
\text { изменения }\end{array}$} & $\uparrow$ & $-/ \downarrow$ & $\uparrow$ & $\downarrow /-/ \uparrow$ \\
\cline { 2 - 5 } & $\downarrow$ & - & $\downarrow$ & $-/ \uparrow$ \\
\hline
\end{tabular}

In the first line of Table 1, there is a situation when the company has to finance its increasing capital expenditures when net income holds constant or even drops. The company will probably draw some debt. But what will happen to the payout? Companies rarely cut their dividends because of strongly negative market reaction to such events. So, when payout decisions are made after investment decisions the debt may be used to maintain some level of payout or to slightly increase it. If it happens, the sign of interrelation will be positive.

However, we have to take into account that decision made in a current year may affect decisions that

${ }^{1}$ Here and afterwards the term "financing decisions" refers to the existing level of debt-to-assets ratio in a company; the term "payout decisions" refers to the existing level of total payout-to-assets ratio in a company. 
would be made in future. For instance, the increase of debt and capital expenditures in year 1 may be the evidence of emerging investment program. This increase may affect the payout decision in year 2 negatively and sign will also be negative. In addition, the company may be in situation when it does not able to draw enough funds to cover both investments and payout. Therefore, the sign of interrelation will depend on what decision has more priority: investment or payout.

In the second line of Table 1 depicted a situation when capital expenditures decrease while net income holds constant. In this case, the company will try to pay some debt using free cash and increase payout (by the amount of decreasing capital expenditures). The sign of interrelation now is negative.

In terms of theory, the payout decisions may be made regardless from investment policy, for instance if shareholders would like to withdraw free cash holdings from management's control [Jensen, 1986]. The sign will be again negative as predicted by agency theory.

We also have to take into account the fact that Secondary Public Offering (SPO) also may be used as the external source of finance. This way of financing does not imply any interest payments that should be made periodically, but usually imply additional dividend payments to the new shareholders (dividend per share can stay the same, bit, for example the ratio of dividend payments to total assets may increase). Simultaneously capital structure (determined as the ratio of total debt to total assets) will decrease.

Let us now discuss some empirical papers that tried to investigate the interrelation between financing and payout decision in the developed countries and emerging markets.

\section{Literature on the interrelation between financing and payout decisions}

To determine whether interrelation between financing and payout decisions truly exists, it is not enough to use one variable as a determinant for another one in a regression equation. We need to take into account the fact that capital structure and dividend policy are endogenous variables, which means that coefficients can be inconsistent. In this case we need to use a system of equations and some special econometrics tools to determine coefficients. Usually these tools include two- or three steps least squares. These two tools allow determining the fact of simultaneous interrelation between two or more endogenous variables between each other (Table 2).

Table 2

Literature dedicated to the interrelation between payout and financing decisions

\begin{tabular}{|c|c|c|c|c|}
\hline Authors and year & $\begin{array}{l}\text { Investigated } \\
\text { interrelation }\end{array}$ & Econometric tools & Period & Sample \\
\hline $\begin{array}{c}\text { Peterson, Benesh, } \\
1983\end{array}$ & & OLS, 2SLS, 3SLS, SUR & 1975-1979 & 534 American companies \\
\hline Dhrymes, Kurz, 1967 & $\begin{array}{l}\text { Investments, financing } \\
\text { and payout decisions }\end{array}$ & OLS, 2SLS, 3SLS & $1951-1960$ & 181 American companies \\
\hline McDonald et al., 1975 & & OI S 2SI S & $1962-1968$ & 75 French companies \\
\hline McCabe, 1979 & & & $1966-1973$ & 112 American companies \\
\hline Yong et al., 2007 & Ownershin structure & OLS, 3SLS & 1997-2002 & $\begin{array}{l}102 \text { South Korean } \\
\text { companies }\end{array}$ \\
\hline Vo, Nguyen, 2014 & $\begin{array}{c}\text { financing and payout } \\
\text { decisions }\end{array}$ & 3SLS & 2007-2012 & 81 Vietnamese companies \\
\hline Jensen et al., 1992 & & OLS, 2SLS, 3SLS & 1982 и 1986 & 565 American companies \\
\hline $\begin{array}{l}\text { Aggarwal, Kyaw, } \\
2010\end{array}$ & $\begin{array}{c}\text { Financing and payout } \\
\text { decisions }\end{array}$ & OLS, 2SLS, 3SLS & 1996-2005 & $\begin{array}{c}3988 \text { developed markets } \\
\text { companies }\end{array}$ \\
\hline Noronha et al., 1996 & & OLS, 3SLS & 1986-1988 & S\&P400 \\
\hline
\end{tabular}


Table 2 shows a classification of existing papers in terms of investigated decisions, tools, and samples. As one can see, in most works authors investigated companies from developed countries (US and Europe). Just two papers used samples from emerging markets (Vietnam and South Korea) [Yong et al., 2007; Vo, Nguyen, 2014]. After looking through all these papers one cannot come up with a clear conclusion on the way of connections between investigated decisions. Some authors conclude that in The United States and some other developed economies, financing and payout decisions are interrelated and made simultaneously [Peterson, Benesh, 1983; McCabe, 1979; Aggarwal, Kyaw, 2010]. These authors point on positive sign of interrelation. In this case, we can talk about signaling: companies use debt to maintain or increase payout and provide markets with positive signals to boost company's stock prices. The other group of authors agrees that the interrelation between financing and payout decisions exists. However, they argue that this interrelation has a negative sign [Jensen et al., 1992; Chen, Steiner, 1999]. This result proves the agency theory, which declares that dividends are used to reduce free cash holdings under the control of managers [Jensen, 1986]. Such companies usually have enough cash to both decrease debt and increase payout. The third group does not find any evidence in the support for hypothesis of interrelation existence [Noronha et al., 1996; Dhrymes, Kurz, 1967; McDonald et al., 1975]. These authors only find evidence for the effect of payout policy on capital structure.

As for the emerging markets (Vietnam and South Korea), results obtained from these samples are quite controversial. In Vietnam authors find out that the interrelation between financing and payout has a negative sign [Vo, Nguyen, 2014], while the sample of Korean companies proves a positive interrelation [Yong et al., 2007]. Based on these two papers one cannot make an unquestionable conclusion on the sign and existence of interrelation between financing and payout decisions.

Now we move to the empirical part of the paper.

\section{Econometric model development}

As was stated previously a very limited amount of papers was dedicated to the problem of interrelation between financing and payout decisions. Even when authors investigate this puzzle on the sample of developed countries, they cannot come up with some unified conclusion. That is why we decided to test our hypotheses not only on companies from emerging markets, but also on the American companies. It will allow us compare the trends in decision-making process between American companies and emerging countries' companies. In addition, the data on American companies seem to be more reliable, so it helped to adjust our model.

We used S\&P Capital IQ database to obtain the necessary data. This base was chosen because of very convenient output interface, reliable and relevant data that were needed in terms of current research. The drawback of the database is a limited time coverage (the data is available from 2007). However, in other databases it is hard to find reliable data on the emerging countries earlier than 2006. Therefore, for the purpose of this paper S\&P Capital IQ is enough. The sample that consists of data for the period of 2007-2013 (for the time of writing this paper 2014 data were not available) allows us obtain the necessary number of observations. This period will show trends of interrelation that took place in the emerging markets recently.

Macroeconomic variables were obtained from the World Bank's database World Development Indicators. Stata package was used for evaluating the econometric model.

The sample of emerging markets' companies consists of the following countries: Argentina, China, South Korea, India, Singapore, Thailand, Russian Federation, Peru and Portugal. Brazil, which is traditionally used in the similar papers, is not taken in the final sample because the Government regulates payout in Brazilian companies (they have to pay out not less than $25 \%$ of their net income). This fact makes the investigation of the interrelation irrelevant. 
Non-financial companies with the market capitalization of more than 50 million dollars were chosen for the sample formation. The final sample consists of 1211 companies from the US and 2445 companies from the developing countries (27 from Argentina, 1183 from China, 33 from India, 744 from South Korea, 18 from Peru, 21 from Portugal, 74 From Russia, 142 from Singapore, 203 from Thailand).

Based on the papers from previous section and obtained samples we can propose the following hypotheses for the companies from developing countries:

1. There is a negative interrelation between the payout-to-assets ratio and debt-to-assets ratio in the companies from developing markets;

2. The negative interrelation between the payout-to-assets ratio and debt-to-assets ratio takes place in both developing [Vo, Nguyen, 2014] and developed countries [Jensen et al., 1992];

3. The specifications of the payout-to-assets ratio and debt-to-assets ratio do not affect the sign of interrelation.

For the econometric analysis of the interrelation between the payout-to-assets ratio and debt-toassets ratio, we construct the following system of equations (1):

$$
\begin{aligned}
& \text { Payout }_{i . t}=\alpha_{0}+\alpha_{1} \text { Payout }_{i . t-1}+\alpha_{2} \text { Debt }_{i . t}+\alpha_{3} \text { CapEx }_{i . t}+\alpha_{4} \text { Cash }_{i . t}+\alpha_{5} \text { ROS }_{i . t} \\
& \sum_{n=6}^{8} \alpha_{n} \text { Macro }_{i . t}+\alpha_{8} i . \text { Company }_{i}+\alpha_{9} i . \text { Year }_{t}+\varepsilon_{i . t} \\
& \{ \\
& \text { Debt }_{i . t}=b_{0}+b_{1} \text { Payout }_{i . t}+b_{2} q_{-} \text {Tobin }_{i . t}+b_{3} \text { CapEx }_{i . t-1}+b_{4} \text { Cash }_{i . t}+b_{5} R O A_{i . t}+ \\
& \sum_{n=6}^{8} b_{n} \text { Macro }_{i . t}+\alpha_{8} i . \text { Company }_{i}+\alpha_{9} i . \text { Year }_{t}+\gamma_{i . t}
\end{aligned}
$$

where:

Payout is a level of payout to shareholders. We use two proxies for this variable: total payout (tot payout), which is the ratio of sum of dividend payout and repurchases to total assets, and dividend payout (div_payout), which is the ratio of dividend payout to total assets;

Debt is a company's capital structure. We use two proxies for capital structure as well: total debt (tot_debt) which is the ratio of sum of short-term and long-term debt to total assets, and the ratio of long-term debt to total assets $(l t$ _debt);

q_Tobin which is the ratio of company's market capitalization to the balance value of company's assets;

CapEx is company's investment policy which is determined as the ratio of capital expenditures to total assets;

Cash is company's cash holdings - the ratio of cash to total assets. This variable will allow us determine the effect of company's cash flows on the payout and debt ratios;

$R O S$ is return on sales (the ratio of net income to sales). This variable will allow us check the effect of accounting performance on payout decisions;

$R O A$ is return on assets (the ratio of sales to total assets). This variable will allow us check the effect of accounting performance on financing decisions;

Macro includes three variables that characterize the macroeconomic environment in emerging countries $^{2}$ : annual inflation rate (infl), natural logarithm of the Gross Domestic Product per capita $\left(\ln \_g d p\right)$ and the ratio of total market capitalization to the countries' GDP (mcap_to $\left.\_d p\right)$; $\varepsilon, \gamma,-$ errors.

In the equations of System (1) we also include two dummy variables: Company and Year. It is necessary to do to take into account the individual effects of companies and time effects - it will help

${ }^{2}$ These variables are used only for evaluating the model with the sample of all emerging countries. 
to consider the panel structure of our data. In the first equation we change ROA with ROS (return on sales, which is the ratio of net income to sales), and in the second - CapEx with Lagged CapEx. It was done to make the set of instruments more diversified to fight endogeneity problem.

We decided to use 3-SLS instead of 2-SLS because it allows consider the possible correlation between the errors, and we cannot be sure that there is no correlation between the errors in our sample.

The next section is dedicated to the evaluation of econometric model and discussion of results.

\section{Results of econometric research}

We start this section with the discussion of descriptive statistics for our samples. In the Table 3, one can see the descriptive statistics for the companies from the United States.

Descriptive Statistics for the US companies.

\begin{tabular}{|r|rrrrr|}
\hline Variable & obs & Mean & Std. Dev. & Min & Max \\
\hline tot_payout & 8477 & .0424362 & .0639445 & 0 & .7413601 \\
div_payout & 8477 & .0119283 & .016816 & 0 & .1152929 \\
tot_debt & 8477 & .2111446 & .168713 & 0 & .9305471 \\
\hline 1t_debt & 8477 & .2000615 & .1644454 & 0 & .9305471 \\
tot_equity & 8477 & .4989126 & .1951127 & .015443 & .975342 \\
capex & 8477 & .0517509 & .0556378 & 0 & .7219008 \\
roa & 8477 & 1.0333 & .7180948 & .0010365 & 5.592559 \\
q_tobin & 8477 & 2.783992 & 2.421139 & .0905953 & 27.73479 \\
\hline cash & 8477 & .1106301 & .1144567 & $2.196-06$ & .8918476 \\
ros & 8477 & .0509536 & .1544405 & -2.0159 & .9864842 \\
\hline
\end{tabular}

It is pretty clear from the Table 3 that the sample is very diversified with very different companies: from the firms that do not pay any dividend (non-payers) to the active payers; from zero-debt companies to the active borrowers: from non-profitable to high-profitable and so on and so forth. We laso can see that there are no extraordinary observations.

Now move to the emerging countries' statistics.

Table 4

Descriptive statistics for the companies from emerging countries

\begin{tabular}{|r|rrrrr|}
\hline variable & obs & Mean & std. Dev. & Min & Max \\
\hline tot_payout & 17115 & .0206493 & .029269 & 0 & .9641296 \\
div_payout & 17115 & .0183471 & .0240281 & 0 & .2635616 \\
\hline tot_debt & 17115 & .2286435 & .1759201 & 0 & .8341463 \\
7t_debt & 17115 & .1146672 & .1357432 & 0 & .8243262 \\
tot_equity & 17115 & .535746 & .1953963 & .0116952 & .9930796 \\
capex & 17115 & .0613106 & .0585649 & 0 & .789001 \\
roa & 17115 & .8902993 & .6412442 & .0000206 & 9.887548 \\
\hline q_tobin & 17115 & 2.457099 & 2.317736 & .1005441 & 19.34641 \\
cash & 17115 & .1309516 & .1177188 & $1.29 e-06$ & .8982147 \\
ros & 17115 & .0567152 & .1919667 & -4.644068 & 2.041667 \\
inf1 & 17115 & 3.925836 & 3.522568 & -1.49161 & 21.21372 \\
7n_gdp & 17115 & 9.070427 & .8984797 & 6.948978 & 10.9184 \\
\hline mcap_to_gdp & 17115 & 84.40683 & 38.99209 & 5.676959 & 196.4032 \\
\hline
\end{tabular}

It is clear from the Table 4, that observations from the sample of developing countries are also very diversified. It is not surprising as we have companies from 9 different emerging countries.

It is very interesting to notice that on average the dividend payout ratio for developing countries is $0.64 \%$ higher than that for American companies and the toptal payout ratio is $2 \%$ less than that 
for American companies. This is probably because the repurchases are now more popular way of distribution of payout to shareholders in the developed than in the developing countries. The total debt ratio on average is almost equal for both American and emerging countries' companies, but it is clear that in the US long-term debt is used more widely (maybe because of time structure of the interest rates or some structural defferences in economies).

\section{Results for the US companies}

At first, we test our hypotheses on the sample of American companies.

Table 5

Results for the companies from the United States $^{3}$

\begin{tabular}{|c|c|c|c|c|}
\hline \multirow{2}{*}{} & \multicolumn{4}{|c|}{3 -SLS } \\
\cline { 2 - 5 } & \multicolumn{2}{|c|}{ Total Payout } & \multicolumn{2}{c|}{ Dividend } \\
\cline { 2 - 5 } & TD & LTD & TD & LTD \\
\hline Payout: & $-0.090^{* * *}$ & $-0.092^{* * *}$ & $0.002^{* * *}$ & $0.002^{* * *}$ \\
\hline Debt & $0.403^{* * *}$ & $0.404^{* * *}$ & $0.935^{* * *}$ & $0.935^{* * *}$ \\
\hline 1.Payout & -0.002 & 0.001 & 0.001 & 0.001 \\
\hline CapEx & $-0.018^{* *}$ & $-0.014^{* *}$ & 0.001 & 0.001 \\
\hline Cash & $0.037^{* * *}$ & $0.037^{* * *}$ & $0.002^{* * *}$ & $0.002^{* * *}$ \\
\hline ROA/ROS & \multicolumn{4}{|l}{} \\
\hline Capital Structure: & $-0.986^{* * *}$ & $-0.939^{* * *}$ & $0.511^{* * *}$ & $0.413^{* * *}$ \\
\hline Payout & $0.092^{* *}$ & $0.013^{* * *}$ & $0.114^{* * *}$ & $0.147 * * *$ \\
\hline 1.CapEx & $0.010^{* * *}$ & $0.010^{* * *}$ & $0.005^{* * *}$ & $0.005^{* * *}$ \\
\hline q-Tobin & $-0.590^{* * *}$ & $-0.550^{* * *}$ & $-0.632^{* * *}$ & $-0.588^{* * * *}$ \\
\hline Cash & $-0.046^{* * *}$ & $-0.048^{* * *}$ & $-0.053^{* * *}$ & $-0.055^{* * *}$ \\
\hline ROA
\end{tabular}

As one can see from the Table 5, there is a significant interrelation between financing and payout decisions in the US companies for all specifications of payout and debt ratios. For the model with total payout ratio there is a negative sign of the interrelation, while lagged capital expenditures affect debt ratios positively. This result can be interpreted as follows: if the company cuts its investments in year 0 , in year 1 it can use free cash holdings for both repaying the existed debt and boost its total payout.

However, for the model with dividend payout ratio the interrelation has a positive sign. As it was stated earlier, the US companies prefer to distribute cash to their shareholders using repurchases instead of dividends. We can assume that if the company faces a bad year (in terms of low or negative net income) it may struggle to pay out some minimum level of dividends using debt finance. On the contrary, if internal sources of finance are enough the company will make a repurchase and it will be considered as some additional payout.

These results allow us make two important conclusions. First, in the United States managers really make decisions on financing and payout simultaneously. Second, the sign of the interrelation may be affected by the specification of payout policy (whether it is total payout ratio or dividend payout ratio). Using the first proxy proves the agency theory, while the second - proves the signaling theory. We explain these differences by the fact that dividends nowadays make up a small fraction of total payout in the US.

The next section discusses results obtained on the companies from emerging markets.

\section{Results from emerging markets' companies}

In the Table 6, one can see results for the sample of companies from all nine emerging countries.

${ }^{3}$ Here and below *p $<0,1 ; *$ p $<0,05 ; * * * p<0,01$. 
Results obtained on the sample of developing countries

\begin{tabular}{|c|c|c|c|c|}
\hline & \multicolumn{4}{|c|}{ 3-SLS } \\
\hline & \multicolumn{2}{|c|}{ Dividend } & \multicolumn{2}{|c|}{ Total Payout } \\
\hline & TD & LTD & $\mathrm{TD}$ & LTD \\
\hline \multicolumn{5}{|l|}{ Payout: } \\
\hline Debt & $-0.012 * * *$ & $0.008 * * *$ & $-0.049 * * *$ & $0.009 * * *$ \\
\hline 1.Payout & $0.424 * * *$ & $0.427 * * *$ & $0.608 * * *$ & $0.631 * * *$ \\
\hline CapEx & $0.013 * * *$ & $0.007^{*}$ & $0.010^{* *}$ & -0.002 \\
\hline Cash & 0.002 & $0.011 * * *$ & $-0.025^{* * *}$ & $0.007 * * *$ \\
\hline $\mathrm{ROA} / \mathrm{ROS}$ & $0.011 * * *$ & $0.011 * * *$ & $0.008 * * *$ & $0.008 * * *$ \\
\hline Inflation & 0.000 & -0.0003 & $-0.0001 *$ & -0.0001 \\
\hline $\ln ($ GPD per capita) & $-0.004 * * *$ & $-0.006^{* * *}$ & $-0.004 * * *$ & $-0.003 * * *$ \\
\hline Market Cap-to-GDP & -0.0001 & -0.0001 & -0.0001 & $0.0070^{*}$ \\
\hline \multicolumn{5}{|l|}{ Capital Structure: } \\
\hline Payout & $-0.759 * * *$ & $0.252 * * *$ & $-0.689 * * *$ & $0.410 * * *$ \\
\hline 1.CapEx & $0.387 * * *$ & $0.418 * * *$ & $0.326 * * *$ & $0.414 * * *$ \\
\hline q-Tobin & 0.000 & $-0.006 * * *$ & $-0.002 * *$ & $-0.006 * * *$ \\
\hline Cash & $-0.550 * * *$ & $-0.303 * * *$ & $-0.554 * * *$ & $-0.303 * * *$ \\
\hline ROA & $-0.019 * * *$ & $-0.038 * * *$ & $-0.019 * * *$ & $-0.039 * * *$ \\
\hline Inflation & $-0.0030 * * *$ & $0.0020 * * *$ & $-0.0030 * * *$ & $0.0020 * * *$ \\
\hline $\ln (\mathrm{GPD}$ per capita) & $-0.0210 * * *$ & $0.0110 * * *$ & $-0.0250 * * *$ & $0.0130 * * *$ \\
\hline Market Cap-to-GDP & $-0.0002 * *$ & $-0.0002 * *$ & $-0.0002 * *$ & $-0.0002 * *$ \\
\hline
\end{tabular}

The obtained results for the sample of nine emerging countries prove our hypothesis about the existence of interrelation between payout and debt ratios (Table 6). The sign of interrelation is negative for the models with total debt ratio (that supports agency theory) and positive - for the models with long-term debt ratio. There can be two reasons for that. First, companies in emerging countries may use only long-term borrowings to finance payouts. Second, the results may be affected by the diversified sample. Therefore, the next step is to evaluate the model for each country separately.

There is a significant interrelation between payout and debt ratios in all nine countries. However, the signs are varied among debt specifications and countries (Table 7). In Argentina, India, South Korea, Peru, Portugal, Singapore and Thailand the sign of interrelation is negative for almost every model. For Russian and Chinese companies the sign is positive for every model (that supports signaling model).

Most developing countries have similar patterns in making financing and payout decisions with the companies from the United States. The only difference is in results for the models with dividend payout ratio. As it was stated earlier, it can be explained by the fact that dividends are less popular nowadays in the US than in the developing countries.

Table 7

Separate results for the companies from different countries

\begin{tabular}{|c|c|c|c|}
\hline Positive interrelation between financing and payout decisions & \multicolumn{2}{c|}{$\begin{array}{c}\text { Negative interrelation between financing and payout } \\
\text { decisions }\end{array}$} \\
\hline Total payout & Dividend payout & Total payout & Dividend payout \\
\hline \multicolumn{2}{|c|}{ China } & Argentina \\
\hline Russia & & South Korea \\
\hline
\end{tabular}




\begin{tabular}{|l|l|c|c|}
\hline & & Peru & \\
\hline & & Portugal \\
\hline & & Singapore \\
\hline & & Thailand \\
\hline
\end{tabular}

Companies from the Russian Federation and China use debt financing to increase payouts to their shareholders. What are the possible reasons for that? Let us look at the descriptive statistics of companies from Russia (Table 8) and China (Table 9).

Table 8

Descriptive statistics for the companies from Russia

\begin{tabular}{|r|rrrrr|}
\hline Variable & Obs & Mean & Std. Dev. & Min & Max \\
\hline tot_payout & 518 & .019827 & .0424808 & 0 & .5408735 \\
div_payout & 518 & .0134995 & .0272507 & 0 & .2131206 \\
\hline tot_debt & 518 & .2486412 & .1697705 & 0 & .6830749 \\
lt_debt & 518 & .2163182 & .1601539 & 0 & .6719254 \\
tot_equity & 518 & .5492685 & .2027401 & .0586794 & .975688 \\
capex & 518 & .093289 & .064746 & 0 & .4217803 \\
roa & 518 & .8061512 & .583239 & .0000545 & 8.81459 \\
\hline q_tobin & 518 & 1.701409 & 1.768136 & .1054664 & 16.60985 \\
cash & 518 & .057235 & .0631509 & .0000134 & .4997488 \\
ros & 518 & .095625 & .1703688 & -1.46203 & .9873 \\
& & & & & \\
\hline
\end{tabular}

From the Table 8, one can see that on average Russian companies use long-term debt more widely than other emerging countries. Moreover, Russian companies use repurchases more widely. These characteristics have some similarities with those of the US companies. Russian companies may use debt financing to maintain some appropriate level of payout to attract new investors. However, we did not find any evidence that Russian companies use repurchases to distribute some additional funds (as the US companies do).

Table 9

Descriptive statistics for the companies from China

\begin{tabular}{|r|rrrrr|}
\hline Variable & 0bs & Mean & Std. Dev. & Min & Max \\
\hline tot_payout & 8281 & .0236615 & .0210847 & 0 & .3298923 \\
div_payout & 8281 & .023195 & .0202659 & 0 & .2635616 \\
\hline tot_debt & 8281 & .2340638 & .1741373 & 0 & .8341463 \\
lt_debt & 8281 & .0963718 & .1249543 & 0 & .7743289 \\
tot_equity & 8281 & .5200739 & .1935913 & .0269279 & .9930796 \\
capex & 8281 & .0640173 & .0561334 & 0 & .5452859 \\
roa & 8281 & .7837027 & .6138635 & .0019732 & 9.30996 \\
\hline q_tobin & 8281 & 3.438337 & 2.547137 & .1148515 & 18.75162 \\
cash & 8281 & .1781549 & .1297303 & .000024 & .8982147 \\
ros & 8281 & .0711177 & .1532121 & -4.312796 & .9826481 \\
\hline
\end{tabular}

From the descriptive statistics of Chinese companies, we cannot find any explanations about possible differences in results between companies from China and companies from other emerging countries. Probably, Chinese companies use debt to maintain some competitive level of payout to attract new investors. Moreover, they use debt to finance their investments, while the increasing profitability leads to increasing payout. 
To sum up, our hypothesis about negative interrelation between debt and payout ratios cannot be rejected for the companies from emerging countries (except China and Russia). It means that the results can be different not only between developed and developing countries but also among the members of these two groups.

\section{Comparison of the results}

Using two samples constructed of the financial data of American and emerging countries' companies, we managed to find some statistically significant results. We successfully employed three-steps least squares method to capture the simultaneous interrelation between debt and payout ratios.

The financing and payout decisions are really made simultaneously and have statistically significant interrelation between each other. There is a negative interrelation for the companies from the United States for the models with total payout ratio and positive - for the models with dividend payout ratio. The specification of capital structure does not affect the results of the US companies. For the sample of nine emerging countries' companies, we found negative interrelation for the models with total debt ratio and positive - for long-term debt ratio. The payout specification did not affect the sign. However, when we investigated emerging countries separately, we found out that the signs of interrelation might vary among countries.

The sign of the interrelation may be sensitive to the debt level specification. Long-term debt ratio and total debt ratio may be interchangeably used in the research on the US companies but not on the companies from the developing countries. These two types of debt ratios are used for different purposes in emerging markets that is why it is reasonable to study them separately. Although payout level specification does not affect the sign of the interrelation in emerging countries, we tend to think that for the research one should always test hypotheses on both specifications.

We also come up with the following conclusions concerning other determinants. First, lagged payout level has positive influence on the current level of payout for every model in the US and in the emerging countries, which supports Lintner's hypothesis. Second, macroeconomic variables affect positively both capital structure and payout level. Third, cash holdings affect the level of debt negatively. However, we did not find any evidence for the positive relation between cash and payout level. Similarly, there is no evidence for the negative relationship between the level of capital expenditures and payout ratios, but positive relationship between capital expenditures and debt ratios really takes place in both samples.

\section{Conclusion}

Payout and financing decisions are really made simultaneously and are jointly determined. There is a negative interrelation between total payout ratio and debt ratios and positive - between dividend payout ratio and debt ratios in the US companies. We tend to think that this result can be explained by the fact that repurchases are now more popular type of payout than dividends in the US. The dividends in the US might be considered as a "minimum" payout level, which will be maintained by any means, including new debt issues. For instance, if the company faces a significant negative change in its net income, it can draw more debt to maintain a dividend payout on its minimum acceptable level. However, when there is a positive change in net income, the company can make a repurchase (which will be considered as an extra payout) and reduce its debt.

In the sample of companies from developing countries, we obtained different results. In most countries (except Russia and China), there is a negative interrelation between debt ratios and payout ratios for all specifications. This result let us conclude that most developing countries follow the same patterns in making financing and payout decisions as the US companies. However, in Russia and China there is a positive interrelation, which means that they draw more debt to maintain competitive levels of payout to attract investors. The reason for such behavior is not obvious and needs further investigation.

To sum up, the main findings are the following: 
1. There is a significant interrelation between debt ratios and payout ratios in companies from both developed and developing countries;

2. The sign of this interrelation might be affected by the specification of the payout decisions (for the US companies) and by the company's home country.

This paper is the first step to check the interrelation between financing and payout decisions on the wide sample of emerging countries (including Russian Federation) and to compare the results with the companies from developed countries. There are still some questions. Why do Russia and China have different signs of interrelation compared to other developing countries? Will we have the same signs if we use other emerging countries or other time window? What will happen if we add an equation for the ownership structure? These questions are still opened for the future research.

\section{References}

1. Abor, J. Bokpin G.A. (2010) Investment opportunities, corporate finance, and dividend payout policy. Studies in Economics and Finance, vol. 27, no. 3, pp. 180-194.

2. Aggarwal R., Kyaw, N.A. (2010) Capital structure, dividend policy, and multinationality: Theory versus empirical evidence. International Review of Financial Analysis, vol. 19, no. 2, pp. 140-150.

3. Chen C., Steiner T., (1999) Managerial ownership and agency conflicts: A nonlinear simultaneous equation analysis of managerial ownership, risk taking, debt policy and dividend policy. Financial Review, vol. 34, no. 1, pp.119-136.

4. Dhrymes, Ph.J., Mordecai K., (1967) Investment, dividend and external finance behavior of firms. Determinants of Investment Behavior (ed. Ferber). New York: National Bureau of Economic Research.

5. Florackis C., Kanas A., Kostakis A. (2015) Dividend Policy, Managerial Ownership and Debt Financing: A Non-Parametric Perspective. European Journal of Operational Research, vol. 241, no. 3, pp. 783-795.

6. Jensen G., Solberg D., Zorn T. (1992) Simultaneous Determination of Insider Ownership, Debt, and Dividend Policy. Journal of Financial and Quantitative Analysis, vol. 27, no. 2, pp. 247-263.

7. Jensen M.C. (1986) Agency costs of free cash flow, corporate finance, and takeovers. American Economic Review, vol. 76, no. 2, pp. 323-329.

8. Lambrecht, B., Myers S. (2012) A Lintner model of payout and managerial rents. Journal of Finance, vol. 67, no. 5, pp. 1761-1810.

9. Lintner, J. (1956) Distribution of incomes of corporations among dividends, retained earnings, and taxes. American Economic Review, vol. 46, no. 2, pp. 97-113.

10. Liu L., Shan L. (2007) What is dividend premium? Financial Management Association annual meeting, Online conference proceedings.

11. McCabe G. (1979) The empirical relationship between investment and financing: A new look. Journal of Financial and Quantitative Analysis, vol. 14, no. 1, pp. 119-136.

12. McDonald J.G., Jacquillat B., Nussenbaum M., (1975) Dividend, investment and financing decisions: empirical evidence on french firms. Journal of Financial and Quantitative Analysis, vol. 10, no. 5, pp. 741-755.

13. Modigliani F., Miller M.H. (1958) The cost of capital, corporation finance and the theory of investment. The American Economic Review, vol. 48, no. 3, pp. 261-297.

14. Miller M., Modigliani F. (1961) Dividend policy, growth and the valuation of shares. Journal of Business, vol. 34, no. 4, pp. 411-433.

15. Noronha G.M., Shome D.K., Morgan G.E. (1996) The monitoring rationale for dividends and the interaction of capital structure and dividend decisions. Journal of Banking and 
Finance, vol. 20, no. 3, pp. 439-454.

16. Peterson P.P., Benesh G.A. (1983) A reexamination of the empirical relationship between investment and financing decisions. Journal of Financial and Quantitative Analysis, vol. 18, no. 4, pp. 439-453.

17. Vo, D.H., Nguyen V.T.Y. (2014) Managerial ownership, leverage and dividend policies: empirical evidence from Vietnam's listed firms. International Journal of Economics and Finance, vol. 6, no. 5, pp. 274-284.

18. YongH.K., Rhim J.C., Friesner D.L., (2007)Interrelationships among capital structure, dividends, and ownership: evidence from South Korea. Multinational Business Review, vol. 15 , no. 3, pp. 25-42.

\title{
ВЗАИМОСВЯЗЬ РЕШЕНИЙ О ВЫПЛАТАХ СОБСТВЕННИКАМ И ФИНАНСИРОВАНИИ НА ПРИМЕРЕ КОМПАНИЙ С РАЗВИВАЮЩИХСЯ РЫНКОВ КАПИТАЛА
}

\author{
Анилов Артем Эдуардович4, Пирогов Никита Константинович ${ }^{5}$
}

\begin{abstract}
Решения в области политики финансирования и политики выплат акционерам во многом определяют экономическую эффективность компании: они оказывают влияние на чистый денежный поток (прямо и опосредованно), а значит, и на стоимость компании, и на благосостояние акционеров. Поиск оптимальной структуры капитала и оптимальной стратегии в области выплат акционерам, которые бы обеспечили максимальную полезность для акционеров, обусловил появление работ, посвященных как детерминантам долговой нагрузки, так и детерминантам дивидендной политики. В подобных работах обычно одна из политик рассматривается в качестве детерминанты для другой, что не позволяет сделать вывод о наличии или отсутствии двусторонней связи. Для определения наличия двусторонней связи необходимо использовать системы одновременных уравнений. Исследователи не могут прийти к единому мнению относительно взаимной зависимости структуры капитала и дивидендной политики.
\end{abstract}

Отсутствие однозначных выводов о взаимозависимости политики финансирования и политики выплат между собой, а также низкая проработка проблемы в развивающихся странах обуславливают актуальность разработки данной темы.

В статье рассмотрены и обобщены основные результаты исследований, посвященных взаимосвязи решений о выплатах и финансировании. Разработана эконометрическая модель, позволяющая определить наличие искомой взаимосвязи в развивающихся странах, а также сравнить результаты с компаниями с развитых рынков капитала.

Статья дополняет уже существующие исследования по следующим направлениям: во-первых, исследуется несколько спецификаций структуры капитала (совокупный и долгосрочный долг) и дивидендной политики (совокупные и дивидендные выплаты). Во-вторых, в оба уравнения включаются макроэкономические параметры. В-третьих, будут проанализированы различия во взаимосвязи между компаниями из США и компаниями из развивающихся стран.

Ключевые слова: структура капитала, политика выплат, развивающиеся рынки капитала, корпоративные финансы

JEL: G32, G35

\section{Список литературы}

1. Abor, J. Bokpin G.A. (2010) Investment opportunities, corporate finance, and dividend payout policy. Studies in Economics and Finance, vol. 27, no. 3, pp. 180-194.

\footnotetext{
${ }^{4}$ Аспирант НИУ ВШЭ. Москва, ул. Шаболовка, д. 26. E-mail: Tema_anilov@mail.ru.

${ }^{5}$ Старший преподаватель НИУ ВШЭ. Москва, ул. Шаболовка, д. 26. E-mail: npirogov@hse.ru.
} 
2. Aggarwal R., Kyaw, N.A. (2010) Capital structure, dividend policy, and multinationality: Theory versus empirical evidence. International Review of Financial Analysis, vol. 19, no. 2, pp. $140-150$.

3. Chen C., Steiner T., (1999) Managerial ownership and agency conflicts: A nonlinear simultaneous equation analysis of managerial ownership, risk taking, debt policy and dividend policy. Financial Review, vol. 34, no. 1, pp.119-136.

4. Dhrymes, Ph.J., Mordecai K., (1967) Investment, dividend and external finance behavior of firms. Determinants of Investment Behavior (ed. Ferber). New York: National Bureau of Economic Research.

5. Florackis C., Kanas A., Kostakis A. (2015) Dividend Policy, Managerial Ownership and Debt Financing: A Non-Parametric Perspective. European Journal of Operational Research, vol. 241, no. 3, pp. 783-795.

6. Jensen G., Solberg D., Zorn T. (1992) Simultaneous Determination of Insider Ownership, Debt, and Dividend Policy. Journal of Financial and Quantitative Analysis, vol. 27, no. 2, pp. 247-263.

7. Jensen M.C. (1986) Agency costs of free cash flow, corporate finance, and takeovers. American Economic Review, vol. 76, no. 2, pp. 323-329.

8. Lambrecht, B., Myers S. (2012) A Lintner model of payout and managerial rents. Journal of Finance, vol. 67, no. 5, pp. 1761-1810.

9. Lintner, J. (1956) Distribution of incomes of corporations among dividends, retained earnings, and taxes. American Economic Review, vol. 46, no. 2, pp. 97-113.

10. Liu L., Shan L. (2007) What is dividend premium? Financial Management Association annual meeting, Online conference proceedings.

11. McCabe G. (1979) The empirical relationship between investment and financing: A new look. Journal of Financial and Quantitative Analysis, vol. 14, no. 1, pp. 119-136.

12. McDonald J.G., Jacquillat B., Nussenbaum M., (1975) Dividend, investment and financing decisions: empirical evidence on french firms. Journal of Financial and Quantitative Analysis, vol. 10, no. 5, pp. 741-755.

13. Modigliani F., Miller M.H. (1958) The cost of capital, corporation finance and the theory of investment. The American Economic Review, vol. 48, no. 3, pp. 261-297.

14. Miller M., Modigliani F. (1961) Dividend policy, growth and the valuation of shares. Journal of Business, vol. 34, no. 4, pp. 411-433.

15. Noronha G.M., Shome D.K., Morgan G.E. (1996) The monitoring rationale for dividends and the interaction of capital structure and dividend decisions. Journal of Banking and Finance, vol. 20, no. 3, pp. 439-454.

16. Peterson P.P., Benesh G.A. (1983) A reexamination of the empirical relationship between investment and financing decisions. Journal of Financial and Quantitative Analysis, vol. 18, no. 4, pp. 439-453.

17. Vo, D.H., Nguyen V.T.Y. (2014) Managerial ownership, leverage and dividend policies: empirical evidence from Vietnam's listed firms. International Journal of Economics and Finance, vol. 6, no. 5, pp. 274-284.

18. YongH.K., Rhim J.C., Friesner D.L., (2007)Interrelationships among capital structure, dividends, and ownership: evidence from South Korea. Multinational Business Review, vol. 15 , no. 3, pp. 25-42. 